\title{
Sistem Penentuan Penerimaan Karyawan Menggunakan Metode Simple Additive Weighting dan Weight Product
}

\author{
Ermin $^{\mathrm{a}^{*}}$, Sunardi $^{\mathrm{b}}$, Abdul Fadlil ${ }^{\mathrm{b}}$ \\ aProgram Studi Magister Teknik Informatika, Fakultas Teknologi Industri, Universitas Ahmad Dahlan, Yogyakarta \\ brogram Studi Teknik Elektro, Fakultas Teknologi Industri, Universitas Ahmad Dahlan, Yogyakarta \\ Naskah Diterima : 21 April 2021; Diterima Publikasi : 2 Agustus 2021
}

DOI: 10.21456/vol11iss2pp117-124

\begin{abstract}
Recruitment errors influence in a decrease of quality, performance, and company revenue. One of the causes is the absence of a method that is applied as a systematically of information system in determining the acceptance of the best prospective employees. This study uses the Simple Additive Weighting (SAW) and Weight Product (WP) methods to build an objective, fast, and accurate of Decision Support System (DSS) in determining employee acceptance. This research case study was applied to the Indonesian Market Traders Cooperative (KOPPI) Sorong City, West Papua Province by involving a number of 10 alternative applicants. This study aims to produce an objective information system and provide convenience in determining the best employees, referring to the determination of 9 criteria obtained from interviews, namely education, work experience, motivation, intrapersonal ability, achievement orientation, sales ability, self-confidence, trustworthy, and work ethic by weighting each. SAW and WP methods are both used to determine the best ranking of all alternative applicants and get the best prospective employees. The information system was built using the Waterfall development method with the PHP programming language and Mysql database. Based on the results of research that has been carried out, it is found that the information system built has $100 \%$ conformity of functionality and compatibility between manual and application system. Both methods provide the same highest alternative to be used as the determination of the best employee acceptance, however it is found that the WP method provides better accuracy and validity than SAW.
\end{abstract}

Keywords: Decision Support System; SAW Method; WP Method

\begin{abstract}
Abstrak
Kesalahan rekrutmen dapat berakibat pada penurunan kualitas, kinerja, bahkan pendapatan perusahaan. Salah satu penyebabnya adalah belum adanya metode yang diterapkan sebagai sistem informasi yang tersistem dalam penentuan penerimaan calon karyawan terbaik. Penelitian ini menggunakan metode Simple Additive Weighting (SAW) dan Weight Product (WP) untuk membangun Sistem Pendukung Keputusan (SPK) yang objektif, cepat, dan akurat dalam penentuan penerimaan karyawan. Studi kasus penelitian ini diterapkan pada Koperasi Pedagang Pasar Indonesia (KOPPI) Kota Sorong Provinsi Papua Barat dengan melibatkan sejumlah 10 alternatif pelamar. Penelitian ini bertujuan untuk menghasilkan sistem informasi yang objektif dan memberi kemudahan dalam penentuan karyawan terbaik, merujuk pada penetapan 9 kriteria yang didapatkan dari wawancara, yaitu pendidikan, pengalaman kerja, motivasi, kemampuan intrapersonal, orientasi prestasi, kemampuan menjual, kepercayaan diri, dapat dipercaya, dan etos kerja dengan melakukan pembobotannya masing-masing. Metode SAW dan WP keduanya digunakan untuk menentukan ranking terbaik dari semua alternatif pelamar dan mendapatkan calon karyawan terbaik. Sistem informasi dibangun menggunakan metode pengembangan Waterfall dengan bahasa pemrograman PHP dan database Mysql. Berdasarkan hasil penelitian yang sudah dilakukan didapatkan sistem informasi yang dibangun mendapatkan 100\% kesesuaian fungsionalitas dan kesesuaian antara perhitungan manual dan perhitungan menggunakan sistem pada SAW dan WP. Kedua metode memberikan alternatif tertinggi yang sama untuk dijadikan sebagai penentuan penerimaan karyawan terbaik, namun demikian metode WP memberikan akurasi dan validitas yang lebih baik daripada SAW.
\end{abstract}

Kata Kunci: Sistem Penentuan Penerimaan; Metode SAW; Metode WP

\section{Pendahuluan}

Kemajuan ilmu pengetahuan dan teknologi mendorong manusia untuk lebih inovatif dan profesional dalam pengelolaan perusahaan. Sumber Daya Manusia (SDM) menjadi faktor utama dalam

*) Penulis korespondensi: erminbuton@gmail.com menjalankan aktivitas perusahaan untuk mencapai tujuan. Kesalahan rekruitmen dapat berakibat pada penurunan pendapatan perusahaan. Penyebab utama dari kesalahan ini yaitu belum adanya metode yang dijadikan sebagai standar sistem informasi dalam penentuan penerimaan karyawan. Perusahaan tidak 
akan mampu mencapai visi dan misinya secara optimal tanpa adanya produktivitas SDM yang efektif dan kompeten (Lusiana, 2016). Hal ini menunjukkan bahwa SDM menjadi aset yang sangat penting dan strategis untuk kemajuan perusahaan.

Sistem Pendukung Keputusan (SPK) merupakan sistem informasi berbasis komputer yang memberi kemudahan dalam menunjang berbagai alternatif keputusan untuk menangani permasalahan secara sistematis (Fatikhatus, 2016). SPK menggunakan sistem yang memanfaatkan komputer sebagai hardware dan sistem sebagai software dalam pengambilan keputusan (Rosadi \& Siti, 2017). SPK dirancang sebagai penunjang pengambilan keputusan diawali dengan identifikasi masalah, pemilihan data yang relevan, dan menentukan data yang digunakan sebagai proses pengambilan keputusan (Bosker, 2015). Beberapa metode yang dapat digunakan dalam SPK diantaranya adalah Analytical Hierarchy Process (AHP), Simple Additive Weighting (SAW), Technique for Orders Reference by Similarity to Ideal Solution (TOPSIS), Weight Product (WP), dan Fuzzy Logic. Hal ini menunjukkan bahwa SPK diyakini mampu memecahkan masalah dengan berbagai alternatif metode.

Penelitian menggunakan metode SAW dalam pengambilan keputusan rekrutmen karyawan pada PT. ABC pernah dilakukan oleh Desi (2020). Hasil yang didapatkan berupa daftar calon karyawan yang berhak menempuh proses wawancara setelah melakukan proses seleksi proses administrasi.

Penelitian lain pernah dilakukan oleh Hanggar (2018) mengenai implementasi metode SAW untuk penentuan penerimaan zakat. Penggunaan empat kriteria dan 60 data uji didapatkan akurasi terbaik sebesar $90 \%$. Penelitian yang dilakukan oleh (Faisal, 2017) mengenai perancangan SPK seleksi siswa berprestasi dengan metode WP pernah dilakukan untuk studi kasus SMK PGRI 3 Malang. Hasil perangkingan siswa berprestasi didasarkan pada data kriteria dan bobot. Perangkingan tersebut dapat membantu guru dalam mengambil keputusan penentuan siswa berprestasi.

Penelitian yang dilakukan oleh Langgeng (2017) yaitu SPK rekrutmen berbasis web dengan metode WP yang dilakukan di PT Tung Mung Tangerang memperoleh hasil dengan memberi kemudahan kepada calon pelamar menemukan informasi lowongan pekerjaan dan mengikuti tes mandiri (online) dan meminimalisir penggunaan kertas serta tersedianya laporan yang cepat dan akurat.

Berdasarkan latar belakang yang telah dipaparkan maka dilakukan penelitian sistem informasi penentuan penerimaan karyawan dengan metode SAW dan WP. Penelitian ini bertujuan untuk menghasilkan sistem informasi yang objektif dan memberi kemudahan dalam penentuan karyawan terbaik berdasarkan parameter perankingan dengan metode manual dan sistem aplikasi dengan harapan sistem yang dibangun mudah, cepat, dan akurat.

\section{Kerangka Teori}

SPK diperkenalkan pertama kali oleh Michael S. Scott Morton pada awal tahun 1970 yang dikenal dengan Decision Support System (DSS). DSS adalah bagian dari sistem informasi yang berbasis komputer. Sistem informasi ini digunakan untuk membantu pengambilan keputusan dalam kondisi semi terstruktur maupun tidak terstruktur. DSS dapat diarahkan untuk mengerjakan analitis dalam kondisi yang kurang terstruktur dan kriteria kurang sesuai. DSS memberikan perangkat interaktif yang memungkinkan pengambilan keputusan menggunakan berbagai analisis dengan model yang telah tersedia (Siregar, 2017).

Database adalah pengelolaan sekumpulan data interaktif yang memberi kemudahan aktivitas untuk memperoleh informasi yang dibutuhkan oleh user. Database digunakan untuk mengatasi permasalahan sistem berbasis berkas. Software yang dirancang untuk mengelola database yang dibutuhkan adalah Database Management System atau DBMS (Tomi, 2018).

MySql adalah software Relational Database Management (RDBMS) untuk mengelola data yang cepat dan unggul. Database menjadi pendukung untuk penyimpanan, pencarian, penyusunan, dan penerimaan data secara afektif. MySql memastikan bahwa proses pengaturan akses data di sekelompok user dapat bekerja secara bersamaan, penyediaan akses yang cepat ke database, dan memastikan bahwa hanya user yang mempunyai otoritas yang memiliki hak akses (Ricki \& Devitra, 2019).

PHP adalah bahasa server-side-scripting yang menyatu dengan HTML untuk membuat halaman web dinamis. Sintak dan perintah-perintah PHP dilakukan di server dan hasilnya dikirim ke browser dengan format HTML. Kode program yang ditulis dalam PHP tidak terlihat oleh client sehingga aman. Rancangan PHP membuat halaman web dengan tampilan yang sama berdasarkan permintaan sesuai dengan isi database menggunakan bahasa pemrograman seperti HTML dan Javascript (Ernawati, 2019).

\subsection{Simple Additive Weighting}

Metode Simple Additive Weighting (SAW) dikenal dengan istilah metode penjumlahan bobot. Konsep dasar SAW adalah mencari penjumlahan bobot dari rating kinerja pada setiap alternatif pada semua atribut. Penggunaan SAW dapat membantu pengambilan keputusan dalam berbagai kasus. Proses perhitungan SAW berdasarkan hasil dengan nilai terbesar kemudian terpilih sebagai alternatif terbaik. Perhitungan dinyatakan sejalan dengan metode ini apabila alternatif terpilih memenuhi kriteria yang telah ditentukan (Aang \& Retno, 2016). 
Langkah menggunakan metode SAW sebagai berikut:

1. Menentukan alternatif $\left(\mathrm{A}_{\mathrm{i}}\right)$

2. Menentukan kriteria yang akan dijadikan rujukan dalam pengambilan keputusan $\left(\mathrm{C}_{\mathrm{j}}\right)$

3. Memberikan nilai rating kecocokan setiap alternatif pada setiap kriteria.

4. Tingkat kepentingan (W) setiap kriteria. $\mathrm{W}=\left[\mathrm{W}_{1}, \mathrm{~W}_{2}, \mathrm{~W}_{3}, \ldots \mathrm{W}_{\mathrm{j}}\right]$

5. Membuat matriks keputusan $X$ yang dibentuk dari tabel rating kecocokan dari setiap alternatif dan kriteria. Nilai $\mathrm{X}$ setiap alternatif $\left(\mathrm{A}_{\mathrm{i}}\right)$ dan kriteria $\left(\mathrm{C}_{\mathrm{j}}\right)$ yang telah ditentukan dengan $\mathrm{i}=1,2, \ldots, \mathrm{m}$ dan $\mathrm{j}=1,2, \ldots, \mathrm{n}$.

6. Melakukan normalisasi matriks keputusan dengan menghitung nilai rating kinerja ternormalisasi $\left(\mathrm{r}_{\mathrm{ij}}\right)$ dari alternatif $A_{i}$ pada kriteria $C_{j}$.

$$
\mathrm{r}_{\mathrm{ij}}=\left\{\begin{array}{lc}
\frac{x_{i j}}{\operatorname{Max}\left(x_{i j}\right)} & \text { Jika jatribut Benefit } \\
\frac{\text { Min } x_{i j}}{x_{i j}} & \text { Jika jatribut Cost }
\end{array}\right.
$$

Parameter $\mathrm{r}_{\mathrm{ij}}$ merupakan rating kinerja yang ternormalisasi dari dari alternatif $A_{i}$ pada atribut $C_{j}$ dengan $\mathrm{i}=1,2, \ldots, \mathrm{m}$ dan $\mathrm{j}=1,2, \ldots, \mathrm{n}$

7. Parameter $x_{i j}$ adalah nilai atribut yang dimiliki setiap kriteria, $\mathrm{r}_{\mathrm{ij}}$ adalah nilai rating kinerja ternormalisasi Max, $\mathrm{x}_{\mathrm{ij}}$ adalah nilai terbesar setiap kriteria $\mathrm{i}$, Min $\mathrm{x}_{\mathrm{ij}}$ adalah nilai terkecil setiap kriteria i, Benefit adalah jika nilai terbesar adalah terbaik, dan Cost adalah jika nilai terkecil adalah terbaik. Hasil dari nilai rating kinerja ternormalisasi $\mathrm{r}_{\mathrm{ij}}$ membentuk matriks ternormalisasi (R). Hasil akhir nilai preferensi $\left(\mathrm{V}_{\mathrm{i}}\right)$ diperoleh dari penjumlahan dari perkalian elemen baris $\mathrm{R}$ dengan nilai bobot preferensi $\mathrm{W}$ yang bersesuaian dengan elemen kolom matriks. Hasil yang diperoleh adalah nilai terbesar yang terpilih sebagai alternatif terbaik. Variabel $\mathrm{V}_{\mathrm{i}}$ adalah ranking untuk setiap alternatif, $\mathrm{W}_{\mathrm{j}}$ adalah nilai bobot ranking dari setiap kriteria, $\mathrm{r}_{\mathrm{ij}}$ adalah nilai rating kinerja ternormalisasi. Nilai $\mathrm{V}_{\mathrm{i}}$ lebih besar mengindikasikan bahwa alternatif $\mathrm{A}_{\mathrm{i}}$ merupakan alternatif terpilih (Anita \& Sri,2017).

$$
V_{i}=\sum_{j=1}^{n} w_{j} r_{i j}
$$

\subsection{Weight Product}

Metode Weight Product (WP) merupakan salah satu metode penyelesaian masalah Multi-Criteria Decision Analysis (MCDA) berupa alternatif keputusan yang dijelaskan dalam sejumlah kriteria keputusan. Masing-masing alternatif keputusan dibandingkan dengan cara mengalihkan bobot setiap kriteria keputusan (Wayan \& Rahmat, 2016). Metode WP adalah metode pengambilan keputusan menggunakan perkalian yang menghubungkan rating atribut. Setiap rating atribut dipangkatkan dengan bobot yang bersangkutan (Ermin, 2020).
Cara penyelesaian menggunakan metode WP sebagai berikut:

1. Mengalihkan semua atribut setiap alternatif dengan bobot sebagai pangkat positif oleh atribut manfaat (benefit) dan bobot sebagai pangkat negatif oleh atribut rugi (cost).

2. Hasil perkalian dijumlahkan untuk menghasilkan nilai setiap alternatif.

3. Mencari nilai alternatif dengan melakukan cara yang sama seperti cara satu, hanya saja menggunakan nilai tertinggi untuk setiap atribut tertinggi untuk setiap atribut benefit dan terendah untuk atribut cost.

4. Pembagian nilai $V$ setiap alternatif dengan nilai standar V(A*) yang menghasilkan R.

5. Diperoleh alternatif terbaik menjadi keputusan. Prioritas pada metode WP ada tiga, yaitu:

1) Prioritas untuk alternatif $A_{i}$

$$
\begin{aligned}
& \mathbf{w}_{\mathbf{j}}=\frac{\boldsymbol{w}_{\boldsymbol{j}}}{\sum \boldsymbol{w}_{\boldsymbol{j}}} \\
& \text { dengan } i=1,2, \ldots, \mathrm{m} \text { dan } \sum w_{j}=1
\end{aligned}
$$

$\mathrm{w}_{\mathrm{j}}$ adalah nilai pangkat positif ialah atribut benefit, dan nilai negatif untuk atribut cost. Penentuan nilai yang lebih ke arah benefit (atribut keuntungan) pangkatnya bernilai positif.

2) Prioritas untuk alternatif $S_{i}$

$$
S_{i}=\prod_{j=1}^{n} x_{i j} w_{j}
$$

Variabel $\mathrm{x}$ adalah nilai kriteria, w adalah bobot kriteria/subkriteria, i adalah alternatif, $\mathrm{j}$ adalah kriteria, $\mathrm{n}$ adalah banyaknya kriteria, dan $\mathrm{n}$ adalah banyaknya kriteria.

3) Prioritas relatif dari setiap alternatif

$$
\mathrm{V}_{\mathrm{i}}=\frac{\prod_{\mathrm{j}}^{\mathrm{n}}=1 X_{i j} W_{j}}{\prod_{\mathrm{j}}^{\mathrm{n}}=1\left(\mathrm{X}_{\mathrm{j}} *\right) \mathrm{W}_{\mathrm{j}}}
$$

dengan * adalah banyaknya kriteria yang telah dinilai oleh vektor $\mathrm{S}$.

\section{Metode}

Pada penelitian ini membagi sembilan kriteria dalam penentuan penerimaan karyawan menggunakan perbandingan metode SAW dan WP dengan kriteria pendidikan, pengalaman kerja, motivasi, kemampuan intrapersonal, orientasi prestasi, kemampuan menjual, kepercayaan diri, dapat dipercaya, dan etos kerja.

Pengumpulan data primer dilakukan melalui wawancara kepada manajer Koperasi Pedagang Pasar Indonesia (KOPPI) di Kota Sorong Provinsi Papua Barat. KOPPI adalah perusahaan yang bergerak di sektor simpan pinjam yang berperan melayani Usaha Kecil dan Menengah (UKM) dalam menyediakan layanan kredit usaha untuk masyarakat. Perusahaan ini berdiri pada tahun 2017 dengan karyawan 
sebanyak 20 orang. Perusahaan bergerak di bidang simpan pinjam. Perusahaan ini melakukan rekrutmen setiap tahun dua kali dengan setiap rekrutmen sekitar 10-15 pelamar berdasarkan perkembangan kebutuhan.

Pengumpulan data sekunder dilakukan dengan cara mempelajari e-book dan jurnal terkait yang pernah dilakukan sebelumnya (Novi, 2020). Kerangka penelitian secara umum dapat dilihat pada Gambar 1.

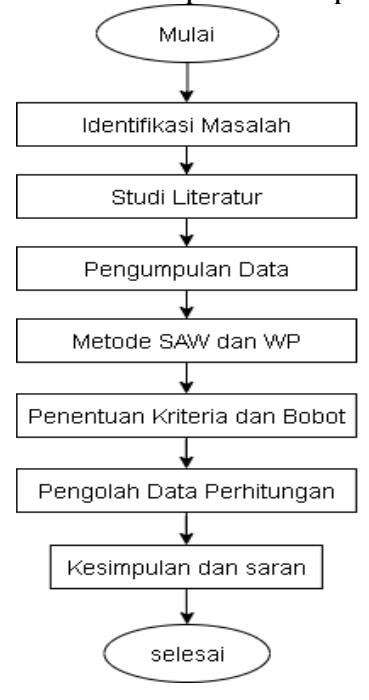

Gambar 1. Kerangka Penelitian

Setiap metode mempunyai kekurangan dan kelebihan. Kekurangan metode SAW adalah perhitungan dilakukan dengan bilangan crisp dan masih menggunakan pembobotan local. Kekurangan metode WP adalah memiliki nilai rentan. Kelebihan metode SAW adalah menentukan nilai bobot untuk setiap atribut dilanjutkan dengan proses perankingan yang menyeleksi alternatif terbaik dari alternatif lainnya. Penilaian lebih tepat berdasarkan nilai kriteria dan bobot preferensi yang telah ditentukan. Sedangkan kelebiham metode WP adalah terdapat variabel cost dan benefit, lebih simple dibandingkan dengan metode lainnya lebih mudah di pahami.

Perancangan sistem dibuat seperti pada Gambar 2 dengan tahapan input, proses, dan output. Penelitian ini menggunakan metode SAW dan WP dengan sembilan kriteria yang berfungsi sebagai variabel input. Metode SAW dan WP digunakan dalam pemrosesan data untuk memperoleh hasil. Output yang dihasilkan adalah alternatif terbaik yang dibutuhkan setiap metode dengan tujuan untuk menentukan hasil yang lebih efektif.

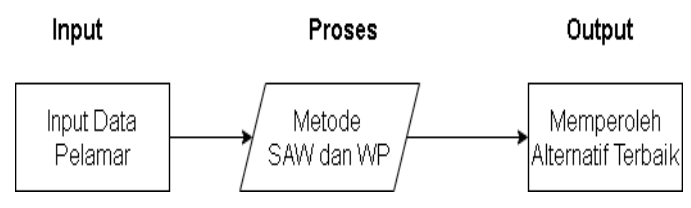

Gambar 2. Rancangan sistem
Penelitian ini dilengkapi dengan perhitungan manual dan pembuatan sistem informasi berbasis web. Sistem yang dibangun menggunakan bahasa pemrograman PHP dan database MySql.

\subsection{Pengolahan Data Kriteria}

Berdasarkan hasil wawancara dengan manajer perusahaan KOPPI, langkah-langkah yang dilakukan untuk memecahkan masalah dengan gabungan metode SAW dan metode WP, yakni menetapkan sembilan kriteria yang dijadikan sebagai rujukan dalam pengambilan keputusan pada Tabel 1. Tingkat kontribusi kriteria diukur berdasarkan nilai pembobotan masing masing kriteria seperti pada Tabel 2. Setiap kriteria kemudian ditentukan nilai prioritas pendidikan (Tabel 3) dan kriteria pengalaman kerja (Tabel 4).

Tabel 1. Kriteria dan Kategori

\begin{tabular}{lll}
\hline Kode Kriteria & Kriteria & Kategori \\
\hline C1 & Pendidikan & Benefit \\
C2 & Pengalaman Kerja & Benefit \\
C3 & Motivasi & Cost \\
C4 & Kemampuan intrapersonal & Benefit \\
C5 & Orientasi prestasi & Benefit \\
C6 & Kemampuan menjual & Benefit \\
C7 & Kepercayaan diri & Benefit \\
C8 & Dapat dipercaya & Cost \\
C9 & Etos kerja & Benefit \\
\hline
\end{tabular}

Tabel 2. Pembobotan Kriteria

\begin{tabular}{ll}
\hline Keterangan & Bobot \\
\hline Sangat Tidak Baik & 1 \\
Tidak Baik & 2 \\
Cukup Baik & 3 \\
Baik & 4 \\
Sangat Baik & 5 \\
\hline
\end{tabular}

Tabel 3. Kriteria Pendidikan

\begin{tabular}{lll}
\hline Pendidikan & Keterangan & Nilai \\
\hline S1 & Sangat baik & $81-100$ \\
D3 & Baik & $70-80$ \\
SMA & Cukup Baik & $60-69$ \\
SMP & Tidak Baik & $50-59$ \\
SD & Sangat Tidak Baik & $40-49$ \\
\hline
\end{tabular}

Tabel 4. Kriteria Pengalaman Kerja

\begin{tabular}{lll}
\hline Pengalaman Kerja & Keterangan & Nilai \\
\hline 3 tahun & Sangat baik & $81-100$ \\
2 tahun & Baik & $70-80$ \\
1,5 tahun & Cukup Baik & $60-69$ \\
1 tahun & Tidak Baik & $50-59$ \\
6 bulan & Sangat Tidak Baik & $40-49$ \\
\hline
\end{tabular}

Kriteria motivasi, kemampuan intrapersonal, orientasi prestasi, kemampuan menjual, kepercayaan diri, dapat dipercaya, dan etos kerja semuanya menggunakan prioritas yang sama seperti ditunjukkan pada Tabel 2. Bobot kriteria digunakan sebagai pengali dengan prioritas di setiap kriteria, kemudian bobot tersebut dinormalisasi menggunakan persamaan (3) Nilai Bobot awal disajikan pada Tabel 5 dan hasil normalisasi diperoleh nilai pada Tabel 6 . 
Tabel 5. Bobot Kriteria

\begin{tabular}{cc}
\hline Kriteria & Bobot \\
\hline C1 & 5 \\
C2 & 4 \\
C3 & 3 \\
C4 & 4 \\
C5 & 4 \\
C6 & 5 \\
C7 & 3 \\
C8 & 3 \\
C 9 & 5 \\
\hline
\end{tabular}

Tabel 6. Normalisasi Bobot

\begin{tabular}{cc}
\hline Kriteria & Normalisasi Bobot \\
\hline C1 & 0,138888889 \\
C2 & 0,111111111 \\
C3 & $-0,083333333$ \\
C4 & 0,111111111 \\
C5 & 0,111111111 \\
C6 & 0,138888889 \\
C7 & $-0,083333333$ \\
C8 & 0,083333333 \\
C9 & 0,138888889 \\
\hline
\end{tabular}

\subsection{Nilai Bobot Metode SAW}

Hasil rangkaian tes kriteria dilakukan dengan 10 pelamar sebagai alternatif $\left(\mathrm{A}_{\mathrm{i}}\right)$ menggunakan sembilan kriteria yang ditetapkan pada Tabel 1 didapatkan hasil yang disajikan pada Tabel 7.

Tabel 7. Nilai Calon Karyawan

\begin{tabular}{cccccccccc}
\hline Alt & C1 & C2 & C3 & C4 & C5 & C6 & C7 & C8 & C9 \\
\hline A1 & 80 & 59 & 4 & 4 & 4 & 3 & 4 & 2 & 3 \\
A2 & 79 & 65 & 3 & 3 & 2 & 3 & 5 & 3 & 5 \\
A3 & 77 & 62 & 3 & 3 & 2 & 4 & 3 & 3 & 4 \\
A4 & 81 & 60 & 4 & 3 & 2 & 3 & 4 & 3 & 5 \\
A5 & 75 & 82 & 4 & 4 & 3 & 3 & 3 & 2 & 3 \\
A6 & 80 & 78 & 3 & 2 & 4 & 3 & 5 & 3 & 3 \\
A7 & 78 & 65 & 4 & 2 & 3 & 4 & 4 & 3 & 4 \\
A8 & 85 & 70 & 3 & 3 & 3 & 3 & 3 & 3 & 4 \\
A9 & 83 & 48 & 4 & 5 & 3 & 2 & 5 & 3 & 3 \\
A10 & 85 & 55 & 4 & 5 & 3 & 2 & 5 & 4 & 3 \\
\hline
\end{tabular}

Data tersebut dilakukan perhitungan nilai bobot kriteria $\mathrm{W}_{\mathrm{j}}$ menggunakan metode SAW dan normalisasi matriks $\mathrm{X}$ dengan persamaan (1) untuk menghitung nilai masing-masing kriteria dari setiap alternatif. Selanjutnya dilakukan perhitungan dengan model yang sama sampai menghasilkan matriks ternormalisasi dengan hasil seperti pada Tabel 8 .

Pada Tabel 8 merupakan matriks ternormalisasi yang dilakukan perhitungan menggunakan bobot kriteria untuk memperoleh perankingan di setiap alternatif untuk mendapatkan nilai $\mathrm{v}_{\mathrm{i}}$.
Tabel 8. Hasil perhitungan setiap kriteria

\begin{tabular}{cllllllll}
\hline C1 & C2 & C3 & C4 & C5 & C6 & C7 & C8 & C9 \\
\hline 0,941 & 0,719 & 0,75 & 0,8 & 1 & 0,75 & 0,8 & 1 & 0,6 \\
0,929 & 0,792 & 1 & 0,6 & 0,5 & 0,75 & 1 & 0,66 & 1 \\
0,905 & 0,756 & 1 & 0,6 & 0,5 & 1 & 0,6 & 0,66 & 0,8 \\
0,952 & 0,731 & 0,75 & 0,6 & 0,5 & 0,75 & 0,8 & 0,66 & 1 \\
0,882 & 1 & 0,75 & 0,8 & 0,75 & 0,75 & 0,6 & 1 & 0,6 \\
0,941 & 0,951 & 1 & 0,4 & 1 & 0,75 & 1 & 0,66 & 0,6 \\
0,917 & 0,792 & 0,75 & 0,4 & 0,75 & 1 & 0,8 & 0,66 & 0,8 \\
1 & 0,853 & 1 & 0,6 & 0,75 & 0,75 & 0,6 & 0,66 & 0,8 \\
0,976 & 0,585 & 0,75 & 1 & 0,75 & 0,5 & 1 & 0,66 & 0,6 \\
1 & 0,670 & 0,75 & 1 & 0,75 & 0,5 & 1 & 0,5 & 0,6 \\
\hline
\end{tabular}

\subsection{Data Nilai Bobot Metode WP}

Hasil rangkaian tes kriteria dilakukan dengan 10 pelamar sebagai alternatif menggunakan sembilan kriteria yang dijadikan sebagai acuan dalam pengambilan keputusan. Kriteria dan kategori disajikan pada Tabel 1. Tingkat kontribusi kriteria diukur berdasarkan nilai pembobotan masing masing kriteria.

Hasil normalisasi bobot pada Tabel 6 digunakan untuk penentuan nilai benefit (keuntungan) yang ditandai dengan pangkat positif dan nilai Cost (pengurangan) yang ditandai dengan pangkat negatif.

Bobot normalisasi digunakan sebagai perkalian data kriteria pada Tabel 7 menggunakan persamaan (4) di dapatkan nilai vektor S yang hasilnya disajikan pada Tabel 9.

Tabel 9. Hasil Vektor S

\begin{tabular}{cc}
\hline Alternatif & Hasil \\
\hline A1 & 5,038698200 \\
A2 & 4,937745310 \\
A3 & 4,732681353 \\
A4 & 4,706378794 \\
A5 & 4,897973983 \\
A6 & 4,854618341 \\
A7 & 4,766128711 \\
A8 & 4,888086349 \\
A9 & 4,575223401 \\
A10 & 4,549943676 \\
\hline
\end{tabular}

Penelitian ini dilengkapi dengan perhitungan manual dan pembuatan sistem informasi. Sistem yang dibangun menggunakan bahasa pemrograman PHP dan database MySql melalui beberapa tahap yang mengacu pada metode pengembangan waterfall seperti dapat dilihat pada Gambar 3. Model waterfall menyediakan pendekatan alur yang berfungsi sebagai perangkat lunak secara terurut mulai dari analisis, desain, pengkodean, pengujian, dan pemeliharaan (Rohmat, 2020). 
Sistem dibangun untuk memberikan perhitungan secara objektif, cepat, dan akurat. Hal ini diperlukan agar dalam penyelenggaraan rekrutmen dengan melibatkan pelamar berapapun dengan dasar kriteria dan bobot yang ditetapkan oleh perusahaan.

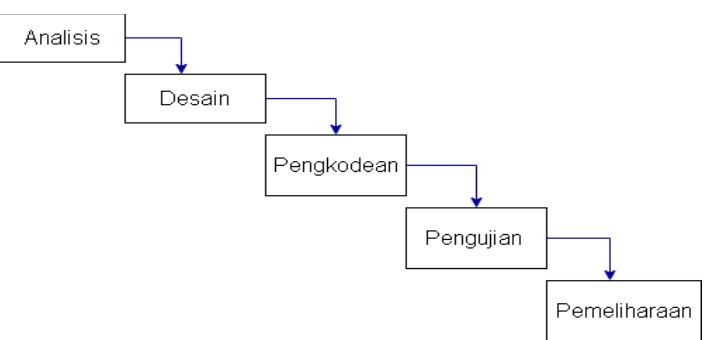

Gambar 3. Metode Pengembangan Aplikasi menggunakan Waterfall

\section{Hasil dan Pembahasan}

Implementasi sistem informasi dibangun berbasis Web dengan sistem operasi windows 10 . Sistem yang dibangun menggunakan bahasa pemrograman PHP dan database MySql. Tahap selanjutnya menunjukkan hasil ranking dari kedua metode kemudian menunjukkan hasil pengujian metode SAW dan WP untuk mendapatkan karyawan terbaik.

\subsection{Hasil Ranking Metode SAW}

Hasil ranking alternatif dengan metode SAW yang dilengkapi dengan bobot dan kriteria didapatkan alternatif terbaik dari persamaan (2) dengan cara mengalikan matriks ternormalisasi dengan bobot kriteria. Hasil SAW berdasarkan nilai konsisten teratas seperti yang disajikan pada Tabel 10 .

Tabel 10. Hasil Perhitungan SAW

\begin{tabular}{ll}
\hline Alternatif & Nilai \\
\hline A1 & 0,810664666 \\
A2 & 0,804660768 \\
A3 & 0,770938879 \\
A4 & 0,763653690 \\
A5 & 0,789215604 \\
A6 & 0,801687699 \\
A7 & 0,778026796 \\
A8 & 0,787906432 \\
A9 & 0,749272593 \\
A10 & 0,748136778 \\
\hline
\end{tabular}

\subsection{Hasil Ranking Metode WP}

Hasil ranking alternatif dengan metode WP didapatkan dari hasil vektor $\mathrm{S}$ dilakukan penjumlahan dan pembagian, didapat alternatif terbaik dari persamaan (5) dengan hitung WP berdasarkan nilai konsisten teratas dan disajikan pada Tabel 11.
Tabel 11. Hasil Vektor V

\begin{tabular}{ll}
\hline Alternatif & Hasil \\
\hline A1 & 0,105087867 \\
A2 & 0,102982378 \\
A3 & 0,098705532 \\
A4 & 0,098156962 \\
A5 & 0,102152901 \\
A6 & 0,101248669 \\
A7 & 0,099403116 \\
A8 & 0,101946683 \\
A9 & 0,095421565 \\
A10 & 0,094894327 \\
\hline
\end{tabular}

\subsection{Metode $S A W$ dan WP}

Berdasarkan perankingan pada dua metode tersebut dilakukan dengan pertimbangan berikut. Jika setiap metode konsisten atau mendapatkan ranking tertinggi yang sama antara metode SAW dan WP maka alternatif tertinggi tersebut dijadikan sebagai alternatif terbaik diantara alternatif lainnya. Hasil perhitungan SAW dan WP disajikan pada Tabel 12 . Nilai konsisten teratas adalah alternatif terbaik. Hasil dari pengujian metode SAW dan WP dapat dilihat pada Tabel 12.

Tabel 12. Pengujian Metode SAW dan WP

\begin{tabular}{cccccc}
\hline \multicolumn{3}{c}{ Metode SAW } & \multicolumn{3}{c}{ Metode WP } \\
\hline Alt & Hasil & Ran & Alter & Hasil & Ran \\
\hline A1 & 0,810664 & 1 & A1 & 0,105087 & 1 \\
A2 & 0,80466 & 2 & A2 & 0,102982 & 2 \\
A6 & 0,801687 & 3 & A5 & 0,102152 & 3 \\
A5 & 0,789215 & 4 & A8 & 0,101946 & 4 \\
A8 & 0,787906 & 5 & A6 & 0,101248 & 5 \\
A7 & 0,778026 & 6 & A7 & 0,099403 & 6 \\
A3 & 0,770938 & 7 & A3 & 0,098705 & 7 \\
A4 & 0,763653 & 8 & A4 & 0,098156 & 8 \\
A9 & 0,749272 & 9 & A9 & 0,095421 & 9 \\
A10 & 0,748136 & 10 & A10 & 0,094894 & 10 \\
\hline
\end{tabular}

Hasil data uji pada Tabel 12 terdapat data urutan ranking yang tidak sesuai pada dua metode, yaitu pada ranking ke-3, 4, dan 5, sedangkan 7 alternatif lainnya memiliki ranking yang sama. Metode SAW didapatkan urutan A6, A5, dan A8 sedangkan metode WP didapatkan urutan A5, A8, dan A6. Perbedaan urutan metode SAW dan WP adalah data yang tidak sesuai (tidak termasuk alternatif terbaik) dan alternatif A1, A2, A7, A3 A4, A9 dan A10 merupakan data yang sesuai (menunjukkan alternatif terbaik). Oleh karena itu didapatkan kesesuaian data, dengan hasil uji 10 alternatif didapatkan sebesar $70 \%$. 


\subsection{Pengujian Fungsionalitas Aplikasi}

Aplikasi telah berhasil dibangun dengan bahasa pemrograman PHP dengan database MySql. Pengujian sistem penentuan penerimaan karyawan perlu dilakukan untuk memastikan sistem informasi yang dibuat dapat bekerja sesuai yang dibutuhkan oleh Perusahaan. Pengujian fungsionalitas sistem dilakukan oleh manajer KOPPI. Hasil pengujian fungsi sistem informasi berbasis web ditunjukkan pada Tabel 13.

Tabel 13. Hasil Pengujian Fungsionalitas

\begin{tabular}{lll}
\hline No & Fungsi & Keterangan \\
\hline 1 & Form login & Sesuai \\
2 & Kelola data kriteria & Sesuai \\
3 & Tambah data & Sesuai \\
4 & Ubah data alternatif & Sesuai \\
5 & Hapus data alternatif & Sesuai \\
6 & Proses perhitungan sistem & Sesuai \\
7 & Tampilan hasil keputusan sistem & Sesuai \\
8 & Ubah nilai kriteria & Sesuai \\
9 & Ubah nilai bobot & Sesuai \\
10 & Keluar & Sesuai \\
\hline
\end{tabular}

Hasil pengujian fungsi sistem dengan 10 fungsi yang ditampilkan pada Tabel 13 memiliki kesesuaian $100 \%$, dengan demikian implementasi fungsionalitas sistem telah berjalan sesuai kebutuhan yang telah ditentukan oleh perusahaan.

\subsection{Pengujian Validitas sistem Informasi}

Sistem yang dibuat selanjutnya dilakukan pengujian validasi untuk menunjukkan bahwa proses perhitungan dengan cara manual dan perhitungan menggunakan sistem aplikasi mendapatkan hasil yang sama. Proses perhitungan dinyatakan valid jika hasil perhitungan yang dilakukan secara manual sama dengan hasil perhitungan yang dilakukan oleh sistem atau dengan kata lain kedua metode menggunakan input yang sama memperoleh keluaran yang sama.

Hasil ranking yang telah diperoleh dari setiap metode didapatkan urutan yang sama antara perhitungan manual dengan perhitungan aplikasi atau validitas $100 \%$, baik pada SAW (Tabel 14) maupun WP (Tabel 15) walaupun ada sedikit perbedaan nilai detail angka di belakang koma karena keterbatasan memori sehingga terdapat pembulatan-pembulatan dalam perhitungan manual. Namun demikian hal ini bukan menjadi persoalan karena memang sistem dibangun untuk mendapatkan nilai yang lebih detail dan akurat.
Tabel 14. Perbandingan Hasil Metode SAW Secara Manual dan Aplikasi

\begin{tabular}{clll}
\hline Alter & Manual & Aplikasi & Selisih \\
\hline A1 & 0,810664 & 0,810577 & 0,000087 \\
\hline A2 & 0,80466 & 0,804580 & 0,000080 \\
A6 & 0,801687 & 0,801598 & 0,000089 \\
\hline A5 & 0,789215 & 0,789133 & 0,000081 \\
\hline A8 & 0,787906 & 0,787834 & 0,000071 \\
\hline A7 & 0,778026 & 0,777961 & 0,000065 \\
\hline A3 & 0,770938 & 0,770872 & 0,000066 \\
\hline A4 & 0,763653 & 0,763589 & 0,000064 \\
\hline A9 & 0,749272 & 0,749189 & 0,000083 \\
\hline A10 & 0,748136 & 0,748058 & 0,000078 \\
\hline & rata-rata & & 0,000076 \\
\hline
\end{tabular}

Tabel 15. Perbandingan Hasil Metode WP secara Manual dan Aplikasi

\begin{tabular}{cccc}
\hline Alter & Manual & Aplikasi & Selisih \\
\hline A1 & 0,105087 & 0,105086 & 0,000001 \\
\hline A2 & 0,102982 & 0,102982 & 0,000000 \\
\hline A5 & 0,102152 & 0,102152 & 0,000000 \\
\hline A8 & 0,101946 & 0,101947 & $-0,000001$ \\
\hline A6 & 0,101248 & 0,101247 & 0,000001 \\
\hline A7 & 0,099403 & 0,099404 & $-0,000001$ \\
\hline A3 & 0,098705 & 0,098706 & $-0,000001$ \\
\hline A4 & 0,098156 & 0,098158 & $-0,000002$ \\
\hline A9 & 0,095421 & 0,09542 & 0,000001 \\
\hline A10 & 0,094894 & 0,094894 & 0,000000 \\
\hline & rata-rata & & $-0,000002$ \\
\hline
\end{tabular}

Berdasarkan Tabel 14 mendapatkan hasil yang sama, hanya saja terdapat kesalahan dalam pembulatan sehingga didapatkan rata-rata 0,000076 dengan metode SAW sedangkan pada Tabel 15 untuk metode WP didapatkan -0,000002. Oleh karena itu dalam perhitungan ini didapatkan metode WP memberikan akurasi dan validitas yang lebih baik dibanding metode SAW, namun demikian yang utama adalah bahwa kedua metode berhasil memberikan hasil perangkingan $100 \%$ yang sama antara cara manual dan aplikasi.

\section{Kesimpulan}

Berdasarkan penelitian yang sudah dilakukan menghasilkan sistem informasi pendukung keputusan menggunakan metode SAW dan WP untuk dijadikan sebagai pertimbangan dalam penentuan penerimaan karyawan. 
Sistem informasi yang telah dibangun menggunakan Bahasa pemrograman PHP dengan database MySql telah mendapatkan 100\% kesesuaian fungsionalitas berdasarkan pengujian oleh perusahaan dan mendapatkan $100 \%$ kesesuaian antara perhitungan secara manual dan perhitungan melalui sistem yang telah dibangun, baik menggunakan metode SAW maupun metode WP.

Kedua metode memberikan alternatif tertinggi yang sama sehingga alternatif tersebut dijadikan sebagai alternatif terbaik diantara alternatif lainnya, walaupun terdapat tiga alternatif di urutan tengah yang memiliki urutan ranking yang tidak sama. Berdasarkan rata-rata selisih yang didapatkan bahwa metode WP memberikan akurasi dan validitas yang lebih baik daripada SAW namun kedua metode berhasil memberikan hasil perankingan $100 \%$ yang sama antara cara manual dan aplikasi.

\section{Daftar Pustaka}

Aang, A.M. dan Retno, A.P., 2016. Perancangan sistem pendukung keputusan seleksi penerimaan pegawai menggunakan Metode SAW pada PDAM Tirta Dharma Tegal. Creative Information Technology Journal 3 (2): 135-148.

Anita, D., Muhamad, S. dan Sri, H., 2017. Sistem pendukung keputusan perangkingan calon siswa baru jalur undangan menggunakan Simple Additive Weighting. Seminar Nasional Teknologi Informasi dan Multimedia, 5 (1): 35-42.

Bosker, S., 2015. Perancangan aplikasi pengambilan keputusan dalam penerimaan pegawai STMIK Pelita Nusantara Medan dengan Menggunakan Metode Fuzzy Simple Additive Weighting. Jurnal Mantik Penusa 17 (1): 24-35.

Desi, P., 2020. Penggunaan Metode Simple Additive Weighting (SAW) dalam Pengambilan Keputusan Rekrutmen Karyawan pada PT. ABC. Techno.Com 19 (1): 45-55.

Ermin, F. dan Abdul F., 2020. Penerapan Metode Weight Product pada penentuan penerimaan karyawan. Cybernetics 4 (1): 9-18.

Ernawati, Asahar, J. dan Sandi, S., 2019. Implementasi metode string matching untuk pencarian berita utama pada portal berita berbasis android (studi kasus: harian rakyat Bengkulu). Pseudocode 6 (1): 77-82.

Faisal, M., 2017. Sistem pendukung keputusan seleksi siswa berprestasi di SMK PGRI 3 Malang Menggunakan Metode Weighted Product (WP). JINTECH 5 (1):119-124.
Fatikhatus, S., Diema, H.S. dan Chandra, S.A., 2016. Perancangan sistem pendukung keputusan pemilihan pelanggan terbaik menggunakan Metode Simple Additive Weighting (SAW) pada bravo supermarket Jombang. Register: Jurnal Ilmiah Teknologi Sistem Informasi 2 (1): 40-50.

Hanggar, W.A.P., Lailil, M. dan Satrio H.W., 2018. Implementasi Metode Simple Additive Weighting (SAW) untuk penentuan penerima zakat. J-PTIIK) 2 (11): 5877-5883.

Langgeng, L., Septian, N., W. Rimadini, A.A. dan Panji, S., 2017. Sistem pendukung keputusan rekrutmen berbasis web dengan Metode Weight Product (WP) Studi Kasus PT. TUNG Mung Tangerang. Semnasteknomedia, 7hlm.

Lusiana, R.N. dan Sutojo, T., 2016. Penerapan Metode Simple Additive Weighting untuk penerimaan karyawan (studi kasus: PT. Sharia Green Land). $8 \mathrm{hlm}$

Muhammad, N.H.S., 2017. Implementasi Weight Product Model (WPM) dalam menentukan pemilihan sepeda motor sport berbasis SPK. Klik 4 (1): 59-70.

Novita, M., Sunardi dan Abdul, F., 2020. Sistem penentuan penginapan dengan metode Promethee. Jurnal Ilmiah Mandala Education 6 (1):12-19.

Ricki dan Devitra, J., 2019. Pendukung keputusan pemilihan perdana persada dengan Metode Simple Additive Weighting (SAW). Manajemen Sistem Informasi 4 (3): 255-265.

Rohmat, I.B., Dyah, A.M. dan Attohiroh, 2020. Implementasi Metode TOPSIS pada sistem pendukung keputusan pemilihan biji kopi robusta yang bernilai mutu. Fountain of Informatics Journal 5 (1):14-20

Rosadi, D. dan Siti, K., 2017. Perancangan Sistem pendukung keputusan seleksi penerimaan karyawan dengan Metode Simple Additive Weighting (SAW). Jurnal Computech \& Bisnis 11 (1): 39-46.

Tomi, L., 2018. Perancangan sistem informasi delivery order pupuk merk trubus berbasis web pada CV. Prabu Siliwangi Padang. Jurnal J - Click 5 (1): 98-106.

Wayan, S., Ika, P.N. dan Rahmat, R., 2016. Sistem pendukung keputusan penerimaan karyawan pada PT. Sultra Inti Roda Perkasa menggunakan Metode Weight Product (WP) dan Simple Additive Weighting (SAW). SemanTIK 2 (1): 129-140. 